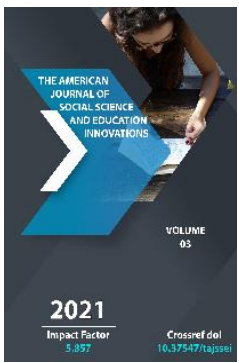

\title{
Dialectics Of Religious And Creative Thinking
}

Jonibek Jumaev

Researcher, Samarkand State University Samarkand, Uzbekistan

Journal Website:

https://theamericanjou

rnals.com/index.php/ta

jssei

Copyright: Original content from this work may be used under the terms of the creative commons attributes 4.0 licence.

\section{ABSTRACT}

This article analyzes the relationship between religious and creative thinking. A brief review of the history, development and current significance of religious thought was made. Creative ideas in the religion of Islam, their impact on the civilization and development of personality society have been studied. The role of creative thinking in creating an innovative environment is revealed.

\section{KEYWORDS}

Religious thinking, creativeness, idea, innovation, creativity, moral perfection, heresy, progress, ability to think.

\section{INTRODUCTION}

The strength that drives progress to action is associated with the formation of a vision capable of new approaches and solutions to real problems. Personality civilization is a promoter of improving the way of life of people. But civilization should not start a person towards dirt, spirituality, abyss. To see a job on the principle of" everything is possible

\footnotetext{
${ }^{1}$ Secular-a philosophical term denoting a secular way of thinking
}

to me " leads to the fact that a person morally perceives himself. Secularism ${ }^{1}$ in the minds of men and sokral ${ }^{2}$ as we look at the positive aspects of the formation and development of knowledge in uniformity, we feel the connected and dependent aspects between their religious and creative thinking.

\footnotetext{
${ }^{2}$ Sokral-inevitability, divine mutuality, religious thinking
} 
If we open the meaning of this word before thinking about creativity, then the question "creative" is derived from English, and "creative" literally means something like "new creation, creative creation". In the case of generalizing these concepts, we can give the following definition: creative thinking is a process that depends on the purposeful upbringing and formation of such characteristics as the primacy of the mind, speed of decision making and not to be afraid of it, loyalty to the task and sphere of work, flexibility of thinking, unconventional nature, non - abstinence from making.

Examples of creativity, which began with the discovery of fire and wheel drive, today walk in the whole universe. Creativity, innovation create comfort in our daily lives, light our weight, close our distance. In this way, creativeness has be-come an integral part of development. [2.50]

\section{MATERIALS AND METHODS}

Creative thinking is also expressed in such characteristics as the speed of thinking, the ability to make independent decisions, confidence in one's own capabilities, the ability to connect distant thoughts with each other, and the breadth of imagination. The creators of our future will have laid the foundation stone for the development of country with the fact that our young people who are considered to have the above characteristics. Islam Karimov, the first president of our state, expressed the following thoughts on the youth of our state: "the future of our homeland, the tomorrow of our people, the reputation of our country in the world community is primarily connected with the growing up and growing up of our children and entering into life as a person. We must never forget this acute truth " [3.1].

A.According to Maslov, creativity is a creative direction that does not suit everyone, but disappears under the influence of the environment from the very end. P.Torrens describes creative thinking as the manifestation of sensitivity to problems, lack or inconsistency of existing knowledge[4].

The concept of "creativeness" reflects cultural diversity in itselfi. For Western men, creativeness is generally considered a novelty. They draw attention to the fact that on the basis of creativeness there is unconventional, curiosity, imagination, a sense of humor and freedom. And the Orientals, on the contrary, understand creativeness as the process of ReBirth of goodness. Although the views of Westerners and Orientalists on creativity are different, however, representatives of both cultures highly appreciate this quality and ownership.

Owners of unusual-minded creative thinking are tirelessly searching for the realization of their own destiny or with their own unique styles [5.13].

The renewal of the style of scientific thought in philosophy and science is not only a general spiritual environment, but also a change in the social image, spiritual world, goals and needs of each member of society. In this regard, the formation of the scientific worldview and way of thinking is the main task of our national philosophy, in which we can see the dialectics of the processes of ideological succession and innovation[6.138].

\section{RESULTS}

If we analyze from a scientific point of view: religion (Arabic-"e'tiqod, trust, obedience) is the belief in the existence of God or gods, supernatural forces. Religion in the Uzbek language means "trust" [7]. When people became enthusiastic and began to worship idols, Allah sent his messengers, that is, His prophets, to express the truth to the rebellious people in order to introduce himself and show mercy to his servants. The prophets, who were considered the legitimate messengers of Allah, always began to submit their people to a 
certain religion, to recognize the uniqueness and uniqueness of Allah, to do good, to be kind, to be compassionate. People of the Times used to worship and worship in different religions.

Umar raziyullahu anhu looked at the worshippers: "religion is to be a dietician of Allah, to refrain from what Allah has forbidden, to follow the lawful and unlawful of Allah," as long as they have proved their boundless love for their religion. As Sultan Ardasher said: "the basis of every nation is religion. And the base of the state is the King. The building, which does not have a solid foundation, quickly shines. The house without the owner soon plundered threeraydi[8.124]. True, there are a lot of religions among the peoples of the world, but each religion has its own unique values, customs, views, culture and even teachings.

The majority of our compatriots during the old shuras were the books of the Koran and Hadith, the main source of our religion, their interpretations and interpretations, the Prophet Muhammad (PBUH).a.v.)and other prophets whose names were mentioned in the Qur'an, were not able to get acquainted with the works about the history of our Islamic religion, morality, halal-Haram, Islamic jurisprudence, Islamic beliefs and prayers. They were unable to carry out research, research, scientific reviews on these rare treasures. The Islamic culture, which brought up the ulugmuhaddis, was condemned as a reactionary culture[9.63].

First President of our country I.A.Karimov by the decree of on March 7,1992, a committee on religious affairs was established under the Cabinet of Ministers of the Republic with the aim of making extensive use of the factor of the Islamic religion and its spiritual opportunities[10.36].

Any innovation, unusual thought, in the opinion of religious fanatics, is called heresy. This is evidenced by their lack of sufficient religious knowledge. After all, finding out that new thoughts and new ideas are not superstitions or superstitions also requires an excellent knowledge from a person. Due to the demand of the times, the attitude of people to religion also changes, is renewed and enriched. In dictionaries, the concept of heresy is described as follows: Bid'at (Arabic bid'at-to introduce news, to create new ones) - indecent news; religious beliefs fail news. Everything that appears to fail in the Qur'an and Sunnah is heresy. Initially, people who were dissatisfied with the Caliph Osman, mostly Shiites and foreigners accused him of heresy in breaking news Contrary to the words and deeds of Muhammad (peace be upon him). Then, when religious-ideological disagreements and disputes arose in the Islamic world, the concept of heresy acquired the meanings of "false or erroneous imagination", "erroneous thought".

There was no clear limit to what to include in the bidet. Faqihdar divides heresy into several types:

- Forbidden heresy-heresy of qadarids, jabariids, murjids and denominations of foreigners;

- Mandub bid'at-Organization of madrasahs, Tarawih prayer with the public:

- Makruh bid'at-works similar to the decoration of mosques;

- Mubah bid'at - to get a hand after the prayer to see, to eat and to let the breadth in the dress;

- Wajib bid'at-works similar to the study of the necessary Sciences.

According to some printers are basically three different:

1. Heresy that leads to unbelief, for example, to ask for help from the dead, those who have disappeared.

2. Heresy, which is forbidden, for example, to make the dead a tool in prayer. 
3. For example, after Friday prayers, read the noon prayer on the careful surface. If a particular deed is considered by representatives of a fiqhid sect as a "noncompliance", that is, a work that fails the Islamic teachings, the adherents of other denominations saw it as a "true path" in accordance with the Qur'an and Sunnah.

The odds in this mode are still there. Let's say, according to the sect of Imam Khomeini, visiting the tombs of the fathers, prayer to the spirit of the ancestors who passed away from the world is considered to be a work of Fatiha reward and is brought to follow. But representatives of the Hanbali sect's Wahhabism flow consider this a heresy.

Taking advantage of this, they want to strike people off the road, causing instability in society. superstitious nonsense also meant nonsense. Widely used in literature in the meanings of superstition, fiction[11.56]. In general, the concept of superstition is not used by people through the acquisition of knowledge, in relation to thoughts that do not cause harm to another person, guide society in the right way with their illusory fantasies, and are progressive. But the interpretation of religious concepts, traditions and rituals in its own way is not provided for by any religious evidence.

We will not be mistaken if we say that the state of the social system at that time when religion came into being was also a cause. Along with the divine religions, the emergence of local religions was also accompanied by the dictates of this period. For example: the fact that the people of Nuh alaihissalom began to pray for idols and rites, the people of Lut alaihissalom resorted to the acts of immorality and fornication, and the Prophet Muhammad alaihissalom was sent by Allah[12.444] because of the outbreak of the time of ignorance was a factor of the social environment.
Islam is the religion of Science and education. And the Qur'an is a book of knowledge. Whoever wants to know the attitude of Islam to science, let him gather the insults of the enemies of religion on one side, let him learn the verses and hadiths related to science from the Holy Quran and Hadith Sharif.In this context, the study of knowledge in the Muslim world, its distribution and its validity have become important in every era. They have been using the contribution of Muslim scholars to the world science so far. The use of the scientific heritage of medieval Muslim scholars was widely accepted. Western scientists admit that in the Middle Ages, Muslims were masters of Europe for no less than six hundred years. The scientist Gustav Lubon says: "the translation of Arabic books, in particular, scientific books, is the only source for teaching, and has served five or six centuries of aging. We can say that the influence of Muslims in some sciences, such as medical science, has reached our present day. In fact, the books of Ibn Sina have been translated since the end of the last century in Monbilia". This scientist says again:"Roger Bacon, Leonard Albezi, Arno Alfifufi, Remon lol, San Toma, great Albert and others believed only in the books of scientists of mususlmon". Mse Renon says: "of course, the great Albert Ibn Sina, while San Toma owes Ibn Rushd in his philosophy." The Orientalist scientist Sediyo says: "the medieval Caspian flag was raised by the Muslims themselves and defeated the barbarism of the northern tribes that shook Europe. They remained "the manabas of Greek philosophy of destruction". They did not stop in front of the treasures of enlightenment that they had achieved, but they threw it away and opened new doors for nature to grow[13.8] ".

Religion in its essence:

- Faith-e'tiqod;

- Sharia, ritual, set of actions;

- Moral and spiritual education; 
- Includes religious knowledge and forms an absolute ideology with a certain system[14.236].

\section{CONCLUSION}

From the above points of view, we come to the following conclusions.

First: The representative of each religion, regardless of which religion, must first of all acknowledge the existence and uniqueness of God Almighty, respect his religion, which he has sanctified according to his will, and perform what he has commanded, correctly and wholeheartedly. Only then in the same human activity there will be development, ascension. Because no divine religion has ever called on people to do evil in their fire.

Secondly: The spirituality, values of a nation do not disappear for a moment, just as they do not appear in a day or century completely muakmmlal. Continuing the centuries-old traditions, we must create new ideas of a new Uzbekistan and strengthen its future path. The formation of the generation of creativeminded people, the formation of the concept of the development of new principles of the ideology of independence in them, and on this basis the creation of the foundations of the upbringing of young people in the patriotism, masculinity and the national spirit is one of the requirements of the modern world.

\section{REFERENCES}

1. Yusupova G. The effectiveness of creative thinking in young people and the formation of a sense of confidence in achieving the goal. The T.: 2014. - P. 7.

2. GS Sultanova, Nurbek Meyliyev. Problems of formation of creative thinking in young people// Наука, образование, теория, практика: новые подходы и актуальные исследования. Росиия.Самара.2021. -Р. 50-54.
3. Karimov I.A. "High spirituality is an invincible force." T.: "Spirituality " 2008. -P. 168.

4. Aksenova V.I., Karandashova R.G. Free development of the student personality: philosophical and psychologicalpedagogical bases of Education. M.: - 2001.

5. Teresa M. Amabail. Creative thinking in business / Trans. from English-M.: Alpina Business Books. The series "Classic Garward Beads Revieww")2006. - P. 13C.

6. S Gulnoza. Science in the hadiths: history and times// Uzbekistan Journal of Oriental Studies 1 (2), 137-146.

7. The wisdom of the predecessors.T.: "Unity".2004, - P. 4.

8. Ahmad Muhammad.The East found the truth. T.: "East". 2006. - P. 124.

9. Muhammad Kemal. History of the prophets.- T.: "New century generation". 2003. - P. 63.

10. Kamariddin Osmanav. History of Uzbekistan. - T.: "Teacher". 2012. -P. 326.

11. Islamic encyclopedia. T.: "National Encyclopedia of Uzbekistan". 2004. - P. 56.

12. Anvar Kari Tursunov the history of the prophets. - T.: "Hullabaloo", 2018. - P. 444.

13. Ahmad Muhammad, Mubashir Ahmad. Islamic Hazor. - T.: "Movarounnahr". 2004. - P. 8.

14. Atamuradov S. Reforms in the sphere of spirituality in Uzbekistan: stages of development, achieved results and prospects. - T.: "Academy". 2011. - P. 236. 